\title{
COMPLEXIDADE RACIAL: mitos e realidades em duas freguesias de Salvador em $1775^{1}$
}

\author{
Pedro de Almeida Vasconcelos*
}

\begin{abstract}
A partir da análise minuciosa dos dados do Censo de 1775 sobre duas freguesias de Salvador (São Pedro e Penha), são colocados em questão cinco mitos dominantes sobre a escravidão no imaginário nacional: (1) o domínio total do trabalho escravo na sociedade; (2) uma sociedade formada apenas por senhores e escravos; (3) uma sociedade constituída, por um lado, por um segmento de dominantes e exploradores e, por outro, por dominados e explorados; (4) uma sociedade urbana segregada; (5) uma sociedade patriarcal, em que as mulheres eram submissas e economicamente subordinadas. Os resultados do censo, portanto, levantam novas questões para o entendimento da complexidade do nosso passado, o que ajuda a entender a manutenção das extremas desigualdades atuais, além de evidenciar a existência de diferenciações espaciais na cidade.

Palavras-chave: escravos, libertos, agregados, freguesias, Salvador.
\end{abstract}

\section{INTRODUÇÃO}

A escravidão teve, no Brasil, uma duração muito longa, ou seja, desde os inícios da colonização até 1888, três séculos e meio que podem ser comparados com apenas um pouco mais de um século do período pós-escravista. Adicione-se a essa longa duração a sua abrangência espacial: a escravidão atingiu todo o território nacional da época. O peso da escravidão, portanto, na formação da sociedade brasileira foi enorme, e, talvez devido à crueldade e à injustiça do sistema escravista, foi elaborada uma série de mitos sobre a sociedade e a escravidão no Brasil. ${ }^{2}$

* Ph.D em Geografia. Professor do Mestrado em Planejamento Territorial e Desenvolvimento Social da Universidade Católica de Salvador (UCSal) e Professor do Mestrado em Geografia da UFBa. pavascon@uol.com.br

${ }^{1}$ Agradeço ao amigo Peter Schweizer pelas numerosas sugestões que foram incorporadas ao texto.

${ }^{2}$ A literatura sobre a escravidão é gigantesca. Podemos destacar, entretanto, sem a pretensão de esgotar o assunto, os textos de Malheiro (1866; 1976); Couty (1881; 1988); Nabuco (1883, 1999); Fonseca (1887; 1988); Moraes (1933; 1986); Goulart (1949; 1975); Ianni (1961; 1988); Cardoso (1962; 1977); Costa (1966; 1998); Verger (1968; 1987); Freitas (1977); Gorender (1978; 1985); Mattoso (1978; 1988); Russell-Wood (1982; 2005); Conrad (1985); Schwartz (1985; 1988); Algranti (1988);
Um primeiro mito que merece destaque especial é o da existência, naquele período, de um domínio total do trabalho escravo. Esse domínio se aplica mais ao que ocorreu no campo (na agricultura ou na mineração), onde o trabalho escravo era essencial, embora em outras atividades rurais, como na pecuária, a escravidão tenha sido complementar. Assim, não era apenas o escravo que trabalhava nessas atividades.

Um segundo mito dominante é o de que a sociedade era formada apenas por senhores e escravos. ${ }^{3}$ A sociedade, sobretudo a urbana, era bem mais complexa e contava com camadas intermediárias, como veremos a seguir.

Outro mito semelhante, e não menos importante, é o da divisão da sociedade em um segmento de dominantes (e exploradores) de um lado, e um segmento de dominados (e explorados) do outro. Seria, pois, uma sociedade formada por senhores ociosos, que viviam fundamentalmente do

Andrade (1988); Lamounier (1988) Maestri (1988; 1991); Silva (1988); Chalub (1990); Gorender (1991); Schwartz (1992; 2001); Soares (2000); Reis (2003); Moura (2004); e Luna; Klein (2005).

${ }^{3}$ O título do livro de Décio Freitas, Escravos e Senhoresde-Escravos (1977), é um exemplo dessa ênfase. 
trabalho escravo. Na realidade, na composição da sociedade daquela época, tanto havia pessoas brancas de diferentes condições sociais que trabalhavam, como havia indivíduos livres e libertos, pardos e pretos, que tinham escravos.

Um quarto mito que merece ser examinado se refere à existência de uma sociedade urbana segregada, ${ }^{4}$ dividida em residentes em sobrados e casas, de um lado, e de residentes em mocambos e senzalas, de outro. ${ }^{5}$ De fato, as cidades não apresentavam, de forma alguma, divisões estanques, apesar da imensa desigualdade social.

Um quinto e último mito é o da existência de uma sociedade urbana patriarcal, na qual a mulher era submissa e não assumia maiores responsabilidades na manutenção da família.

\section{UM MINUCIOSO EXAME DO CENSO DE 1775}

Os dados relativos às freguesias de São Pedro e da Penha, na cidade de Salvador, originários do censo realizado em 1775, são muito ricos e nos oferecem detalhes tais como: o número das casas; nome dos pais de família; suas idades; suas qualidades (cor); seus estados (civis); seus empregos; nome das mulheres, filhos e filhas; idade das mulheres, filhos e filhas; número de escravos; nome e qualidade dos agregados; idade dos agregados; emprego dos agregados; nome das mulheres, filhos e filhas dos agregados e suas idades; e escravos dos agregados. ${ }^{6}$

A análise detalhada dos dados nos permite colocar em dúvida várias dessas afirmações ou mitos, alguns já quase consagrados, sobre a situação racial e sobre a escravidão no período colonial. A situação de Salvador é específica e não pode ser extrapolada para outras cidades brasileiras, que certamente receberam um impacto menor da es-

${ }^{4}$ Sobre a questão da segregação residencial, ver Vasconcelos (2004).

${ }^{5}$ Os dois livros clássicos de Gilberto Freyre, escritos nos anos 30, servem de exemplo dessa evocação: Casa Grande e Senzala e Sobrados e Mucambos.

${ }^{6}$ O mapa da freguesia da Penha, entretanto, não traz as informações relativas às mulheres. cravidão. ${ }^{7}$ Mas, apesar das singularidades, o assunto não perde o interesse. Ao contrário, merece ser estudado à luz dos dados concretos existentes, e não de percepções intuitivas individuais, sem fundamento, que podem influir na concepção e interpretação da realidade racial brasileira daquele período.

A freguesia de São Pedro corresponde ao primeiro desenvolvimento extramuros da Cidade Alta em Salvador, após as portas de São Bento, em direção ao sul. Para sua análise, utilizaremos os dados reproduzidos por Costa em 1965. A segunda freguesia, a da Penha, corresponde, em grande parte, à atual península de Itapagipe, no lado norte da Cidade Baixa. Sua análise se apoiará na cópia do Mapa do Arquivo da Marinha de Ultramar, da Biblioteca Nacional de Portugal. ${ }^{8}$

Segundo a descrição do vigário da paróquia de São Pedro, em 1757, “Compõe-se essa Matriz de soldados [...] e de gente de pouca utilidade, sendo os nobres poucos, por não haverem nesta Matriz grandes edifícios, por ser a mayor parte cazas pequenas [...] e térreas". Quanto à freguesia da Penha, o vigário de Santo Antônio, da qual ela fazia parte naquele ano, comentou que Itapagipe de baixo era um "lugar cituado de alguns Pescadores, e de várias rocinhas, e alguns de varias pessoas moradores na cidade nas quaes tem algum escravos". 9

Em 1775, a composição social da freguesia de São Pedro já era bastante diferenciada da existente na freguesia da Penha, pois contava, entre seus residentes, com desembargadores, procuradores, além de dezenas de moradores que viviam de rendas, de seus bens ou de seus negócios, com pardos e pretos incluídos nessa última categoria. Já na freguesia da Penha predominavam soldados e pescadores, e apenas três indivíduos viviam de seus bens, além de um capitão-mor e um proprietário de alambique.

\footnotetext{
7 A comparação com o Rio de Janeiro (KARASH, 2000) e Recife (CARVALHO, 2002), porém, é pertinente.

${ }^{8}$ Agradeço ao amigo Mauricio Abreu pelo envio de cópia desse rico material.

${ }^{9}$ Amaral, in Accioli, (1937, p. 373, 375), apud Vasconcelos, (2002, p. 108, 117).
} 
Antes de continuar a análise do censo, é da maior importância destacar que, ao contrário dos Estados Unidos, onde o número de libertos era diminuto, ${ }^{10}$ no Brasil, o número de libertos e livres pretos e pardos era muito elevado e, em Salvador, essa era uma realidade comprovada.

No caso da freguesia de São Pedro, estão registradas, no censo, 92 casas com chefes de família pretos $(17,6 \%)$ e 82 casas com chefes de família pardos e cabras $(15,7 \%) .{ }^{11}$ Ou seja, em pleno período da escravidão, essa freguesia contava com um terço (33,3\%) de chefes de família "de cor", que conviviam num mesmo espaço urbano. Os chefes de família registrados como brancos correspondiam a 348 casas, ou seja, $66,5 \%$ dos domicílios então existentes. No caso da freguesia da Penha, a proporção de libertos e de livres "de cor" era ainda mais elevada, $48,1 \%$, quase a metade das famílias, sendo $28 \%$ delas $(75)^{12}$ chefiadas por pretos e $20,1 \%$ (54) por pardos e cabras. As famílias com chefes brancos correspondiam à metade, ou seja, $50 \%$ do total. Nesse cálculo não estão incluídos os escravos (Tabela 1).
Não havia qualquer tipo de segregação espacial entre os residentes, pois os vizinhos eram de diferentes cores, apesar da enorme desigualdade social. Como exemplo, na casa de número 156 da freguesia da Penha, residia o capitão-mor do Forte de Itapagipe, Felix Jozé de Barros, branco, casado, com 50 anos. Seus vizinhos eram a costureira Anna M. Mendes, preta, viúva, com 30 anos, na casa de número 155, e João Felix, preto, casado, com 30 anos e sem profissão definida, na casa de número 157. O mesmo ocorria com o sargentomor das marinhas do Pirajá, o branco Caetano [ilegível], casado, com 70 anos, residente na casa de número 282. Ao seu lado, na casa de número 281, residia Felis [ilegível], preto, solteiro, pescador, com 60 anos e na casa de número 283, Inocência [ilegível], parda, viúva, costureira, com 50 anos de idade.

Mais interessante ainda é o caso da existência de casas "mistas" (prédios): encontramos, em ambas as freguesias da cidade de Salvador, indivíduos de cores diferentes que residiam nos mesmos endereços, certamente em diferentes andares

Tabela 1 - Alguns dados do Censo de 1775 sobre as Freguesias de São Pedro e da Penha em Salvador

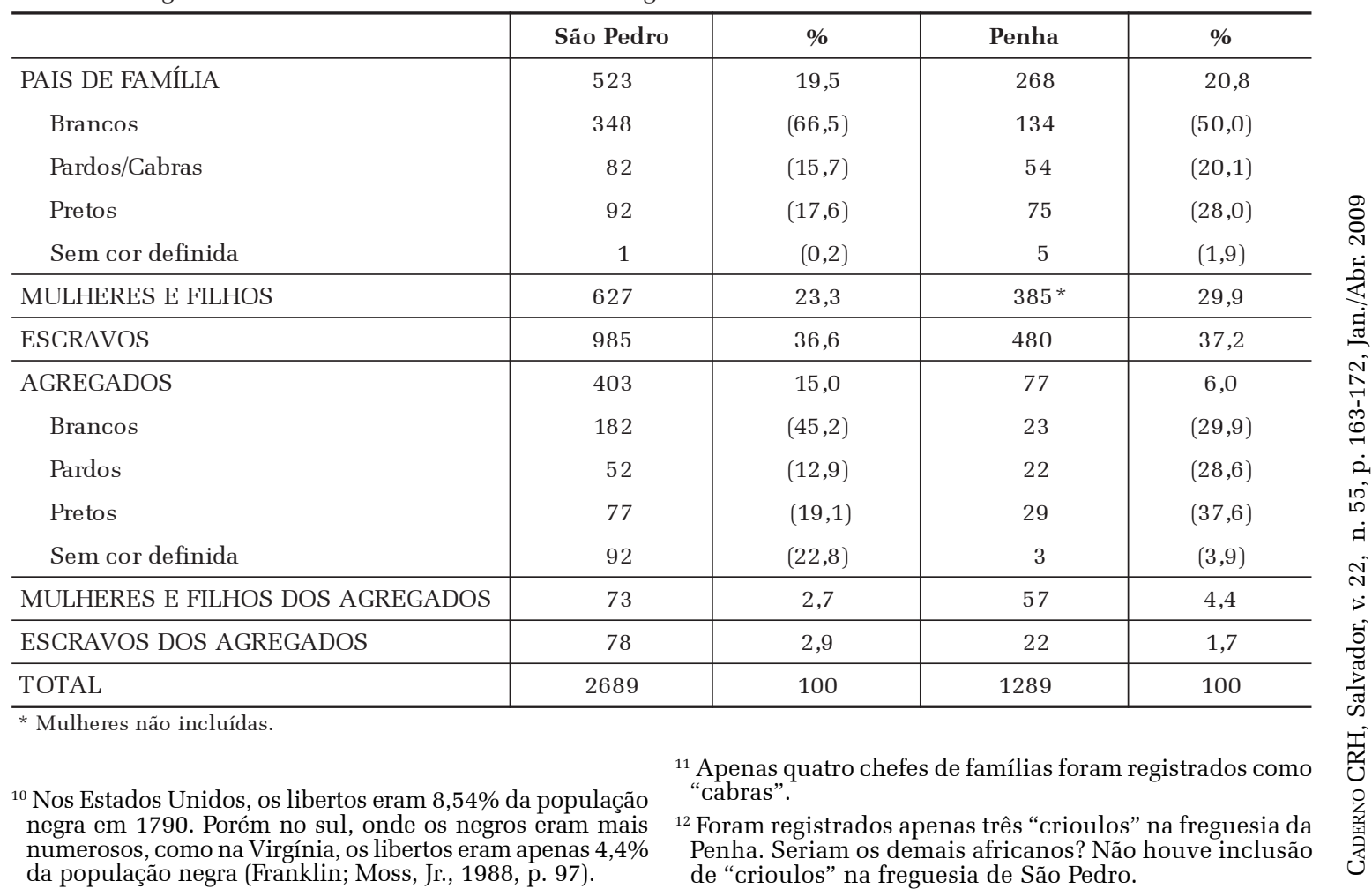


ou nos fundos e quintais. Na freguesia de São Pedro, oito brancos residiam nos mesmos endereços que quatro pardos e quatro pretos, de níveis sociais diferenciados, como um desembargador branco, um carpinteiro pardo (casa número 12), ou um médico branco e um marceneiro preto (casa 580), ou um capitão de artilharia e um sapateiro preto (casa 649), ou de níveis sociais semelhantes, como um pescador branco que residia no mesmo endereço de uma ganhadeira ${ }^{13}$ preta (casa 260).

Outro caso interessante era o da casa de número 135, onde residiam um guarda da alfândega branco, um oficial de sapateiro preto, uma costureira branca e uma ganhadeira preta. Na freguesia da Penha, as diferenças sociais eram menores, com exceção da casa de número 235, na qual estão registrados um clérigo branco e uma costureira preta. Os demais casos são de níveis semelhantes: na casa 162, residiam um carpinteiro pardo e um carpinteiro branco; e, na casa 312, uma costureira branca e um soldado e pescador preto. Finalmente, na casa 321, uma costureira parda residia junto a um branco, militar, que trabalhava também em um alambique. A ausência de segregação, portanto, não era apenas em termos de vizinhança, mas era encontrada, também, nos prédios, sem mencionar a presença dos escravos.

Outro aspecto notável constitui-se na elevada importância das mulheres como chefes de família ("país de família”). Na freguesia de São Pedro, elas respondiam por 44\% do total das casas (348), das quais 39\% (136) tinham chefes de família brancas; 40 das 92 casas com chefes de família pretas (43\%) e mais da metade das casas chefiadas por pardas: 52\%, ou seja, 43 das 82 casas. Na freguesia da Penha a percentagem geral é menos elevada, $35,9 \%$, e, nesse caso, são as chefes de família pretas que apresentam o índice mais elevado: $49,3 \%$ (37 sobre 75 casas), seguidas pelas pardas, 44,4\%

${ }^{13}$ Ganhadeira: atividade relativa ao trabalho no ganho. A referência original era ao trabalho escravo "no ganho", ou seja, o escravo trabalhava durante um período e trazia uma quantia combinada com o senhor. O saldo eventual ficava com o escravo para sua manutenção e pecúlio. As principais atividades eram as de carregador ou de venda em tabuleiros. O termo teve continuidade com os trabalhos semelhantes realizados pelos libertos.
(24 sobre 54 casas) e com uma proporção bem menor entre as brancas, 24,4\% (33 sobre 134). De qualquer maneira, esses indicadores são importantes e mostram que o fenômeno da predominância das mulheres na manutenção de uma família tem raízes bastante antigas na sociedade urbana brasileira. $^{14}$

A informação disponível com maior detalhamento e de grande interesse é a distribuição das profissões e ocupações urbanas, por grupos "raciais", numa cidade no período colonial. No caso da freguesia de São Pedro, as informações sobre as profissões, confirmam a presença de ocupações de prestígio, como cinco desembargadores, sete procuradores, um tabelião, seis escreventes, três escrivães, um feitor de contrato, todas elas desempenhadas pelos declarados brancos. Outras atividades podem revelar uma concentração de riqueza, como os 43 indivíduos que viviam de rendas, de seus bens e de seus negócios, ao lado de atividades menos "nobres", como aquelas exercidas por dez traficantes, dez vendeiros, sete negociantes e três mercadores. De fato, a atividade mais numerosa dos brancos era a dos artesãos, que totalizavam 111 chefes de família, dos quais 53 eram costureiras e 15 sapateiros, ou seja, atividades muito próximas da pobreza. Estão também registradas duas engomadeiras brancas, e, sobretudo, 34 pobres, além de cinco que viviam de esmolas e um cego. Aqui podemos levantar outra observação importante, que se refere à presença de brancos em condições de vida simples e mesmo de pobreza, em uma sociedade escravocrata. Esses exemplos contrariam a expectativa e até a crença de que os brancos não trabalhavam numa sociedade escravocrata.

Na freguesia da Penha, o número de ocupações dos brancos de maior status ou de maior riqueza era mais reduzido: um capitão-mor, um sargento-mor, um proprietário de alambique e apenas dois brancos que viviam de seus bens, um dos quais era cego. $\mathrm{O}$ que se destaca era a grande quan-

14 Sobre o caso de São Paulo no século XIX, ver Dias (1995). 
tidade de atividades no limite da pobreza: 23 costureiras, 19 pescadores, 18 carpinteiros, nove soldados, e, sobretudo a combinação da ocupação de soldado com outra atividade: havia soldado-pescador (16), soldado-carpinteiro (3), soldado-rendeiro, soldado-marceneiro, soldado-calafate, soldado-sapateiro, soldado-vendedor e soldado-roceiro. Outras combinações eram possíveis, como a de capitão de assalto-pescador, seleiro-roceiro e pescador-vendedor de telhas. Os brancos pobres são um homem aleijado e outro que vivia de esmolas.

Entre os chefes de família pardos, os artesãos eram os mais numerosos na freguesia de São Pedro (44), destacando-se, no caso das brancas, 20 costureiras, além de seis alfaiates. Os soldados eram pouco numerosos, apenas três. As profissões de maior prestígio ou rendimento eram aquelas dos que vivem de seus bens (três), os vendeiros (dois) e os traficantes (dois), um mestre escola, um escrevente e um cobrador. Uma única ganhadeira foi classificada como "cabra”. Estão registrados oito pobres e dois que viviam de esmolas. Na freguesia da Penha, a situação dos pardos era diferente: embora predominassem as costureiras (15) e dois alfaiates, os pescadores eram também numerosos (15). Aparecem um músico, um pintor e um estofador, atividades que requeriam maiores habilidades. Encontramos, também, algumas combinações como soldado-pedreiro e soldado-carpinteiro. Não há indicações de pardos pobres nessa freguesia. Essas informações nos mostram as atividades possíveis para os livres e libertos pardos no período colonial.

Quanto aos chefes de família pretos, na freguesia de São Pedro, os artesãos também eram a categoria mais numerosa (31), com um número mais elevado de sapateiros (seis), ficando as costureiras com a mesma quantidade dos alfaiates e pedreiros (cinco), o que os diferencia dos pardos. Uma atividade importante era a de ganhadeira (21), o que indica a continuidade de uma atividade típica dos escravos urbanos. As atividades de maior prestigio ou rendimento eram aquelas dos que viviam de seus bens (três), vendeiros (quatro), procurador (um) e um artesão especializado (imaginário). En- tre os pretos, encontramos o registro de seis pobres, três que viviam de esmola e dois cegos. $\mathrm{Na}$ freguesia da Penha, dominavam as combinações de soldado-pescador (11), soldado-alfaiate, soldado-calafate, soldado-pedreiro, soldado-barbeiro, soldado-roceiro. Apenas um estava registrado como soldado, o que indica a dificuldade de sobrevivência nessa profissão sem o complemento de outra atividade. Os pescadores também eram numerosos (nove). Entre as mulheres, as ganhadeiras eram as mais numerosas (14). As atividades de maior prestígio e rendimentos eram as de armador, de oficial carpinteiro (ambos "crioulos"), de rendeira e de negociante de farinha, atividades bastante modestas. Havia, portanto uma clara diferenciação entre libertos pardos e pretos.

Uma categoria especial era a dos agregados, que se adicionavam às famílias e aos escravos nas residências de Salvador. Na freguesia de São Pedro, os agregados brancos eram muito numerosos: 182 . A maior parte não tinha profissão (65), ou era constituída de viúvos e viúvas (22), ou pobres (16), além de um que vivia de esmolas, de um cego e de um "doido", o que mostra uma situação de elevada precariedade entre os brancos em pleno período escravista. Por outro lado, havia ocupações de nível mais elevado ou de maior rendimento entre os agregados brancos, como a de rendeira (três), um dizimeiro, ${ }^{15} \mathrm{um}$ procurador, um escrevente, um clérigo e um traficante. Na Penha, os agregados brancos eram bem menos numerosos (23), e a ocupação de maior efetivo era a de pescador (oito). Podemos destacar a existência de um proprietário de negócio, um negociante de farinha e um mestre de lancha, o que confirma as diferenças sociais entre as duas freguesias. Um caso único encontrado refere-se à informação de um agregado índio, de 10 anos, que residia com uma costureira branca.

Quanto aos agregados pardos, eles eram 52 na freguesia de São Pedro. Sua situação era bastante precária: 19 sem profissão, nove pobres e um que vivia de esmolas, além de dois cegos. A

${ }^{15}$ Dizimeiro era o indivíduo que cobrava os dízimos da Coroa. 
atividade mais numerosa era a de costureira (11), situação semelhante à das chefes de família pardas. As ocupações mais elevadas eram as de rendeira, de pintor e de alfaiate. Na freguesia da Penha, os agregados pardos eram apenas 22, sendo nove costureiras, e cinco sobre as quais não existem informações.

Dos 77 agregados pretos da freguesia de São Pedro, 29 estavam registrados como indivíduos sem profissão, o que, adicionando-se os 13 pobres aos três que viviam de esmolas e três cegos, mostra também uma situação de elevada precariedade. A ocupação mais numerosa era a das ganhadeiras (oito), seguida das costureiras (cinco). As ocupações de maior prestígio eram as de um capitão dos Henriques, ${ }^{16}$ de um sargento e de um sacerdote. Entre os 29 agregados pretos da freguesia da Penha, nove estão sem informações, e apenas a ocupação de pescador se destaca (cinco). A situação dos agregados pretos também se diferencia da dos agregados pardos.

O exame das profissões dos brancos, chefes de família, sobretudo dos agregados, mostra que, em pleno período escravista, havia uma destacada precariedade, mesmo na camada branca dominante. A situação de chefes de família e de agregados pardos e pretos ainda é mais grave, embora alguns livres e libertos de cor conseguissem uma certa ascensão social ainda no período colonial.

O último mito que deve ser devidamente esclarecido é o de conceber a existência, naquela época, de uma sociedade formada apenas por senhores e escravos. O exame da situação dos escravos, nas duas freguesias, é que demonstra a existência dos maiores contrastes e mostra a "normalidade" da propriedade escrava, tanto entre as "raças", como entre as categorias sociais. De fato, os escravos eram numerosos: 1.063. Estava registrado, na freguesia de São Pedro, um número bastante superior ao de pais de família da freguesia (523) e dos agregados (403) em conjunto, correspondendo a 39,5\% da

${ }^{16}$ Regimento formado por soldados negros em homenagem ao comandante negro Henrique Dias, que combateu os holandeses no século XVII e que teria conseguido "foros de cavaleiro Fidalgo da Casa d'El Rey" (Carneiro, 2005, p. 491) população recenseada. Na freguesia da Penha, o total de escravos registrados era de 502 indivíduos, também superior ao número de pais de família (268) e de agregados (77). Mas a distribuição dos escravos era bastante complexa. Na freguesia de São Pedro, verificou-se que mais da metade dos domicílios não tinha escravos (54,5\%) e que o mesmo ocorria na freguesia da Penha (51,8\%). Ou seja, apesar da escravidão dominante, mais da metade das famílias urbanas vivia sem o apoio ou a exploração do trabalho escravo.

Apesar de menos da metade das famílias ter escravos em ambas as freguesias examinadas, alguns chefes de família, sobretudo brancos, concentravam um volume importante de escravos, embora o maior número seja encontrado entre aqueles que tinham três, dois ou apenas um escravo.

No caso dos brancos da freguesia de São Pedro, um negociante, Bernardino Magalhães, tinha 46 escravos (!) e um segundo, Frutuoso Vicente Viana, tinha 27. Um traficante (Francisco da Mota) tinha 16 escravos, e outro negociante (Joze Caetano), 14. Entre aqueles que viviam dos seus bens, uma viúva (Mariana da Silva) tinha 18 escravos. Entre os militares, um mestre de campo (Jerônimo Pereira Sodre) tinha 22 escravos. Um cirurgião e um escrivão tinham, cada um, 12 escravos. Entre os 10 clérigos que tinham escravos, dos 15 registrados, um cônego chanceler (Bernardo Germano) tinha onze. Os artesãos não tinham efetivos muito elevados: o que possuía o maior número era um carpinteiro (com nove escravos). Até entre as ocupações mais simples havia a posse de escravos: uma engomadeira tinha seis. Um sem profissão tinha cinco. Um pobre tinha dois e outros nove pobres tinham um escravo cada. De fato, 24 famílias tinham três escravos, 37, dois e 56, um escravo cada. Alguns agregados brancos também tinham escravos, como o clérigo Dr. Felix, que possuía nove, e uma viúva, que possuía oito. No total, 21 agregados brancos possuíam 60 escravos.

Na freguesia da Penha, o maior proprietário branco de escravos era um familiar, ${ }^{17}$ que possuía

${ }^{17}$ Indivíduo selecionado para investigar para o tribunal da Inquisição (Silva, 2005). 
uma fábrica de alambique (Manuel João Coimbra), com 37 escravos. Um artesão, calafate, tinha 16 escravos. Um cego, que vivia de sua roça, tinha nove escravos, e um clérigo, oito. Nessa freguesia, 16 chefes de família brancos tinham três escravos, 19 tinham dois e 27 tinham um escravo. Entre os agregados brancos, uma costureira tinha quatro escravos, outra costureira e um pescador tinham um escravo cada, situação bastante diferente da freguesia de São Pedro.

É importante destacar que os livres e libertos de cor também possuíam escravos, embora numa proporção menor do que aquela encontrada entre os brancos. Em São Pedro, 25,6\% dos pardos tinham escravos (21 sobre 82 ) e $25 \%$ dos pretos também tinham escravos (23 sobre 92). Na freguesia da Penha, os pretos e pardos tinham a mesma proporção - 33,3\% (25 sobre 75 e 18 sobre 54 ) -, fato revelador de que entre um quarto e um terço das famílias de libertos e livres de cor, nas duas freguesias, possuía escravos.

Entre os chefes de família pardos da freguesia de São Pedro, uma padeira viúva (Maria Nunes) tinha o enorme contingente de 24 escravos, ou seja, ela era a terceira maior proprietária de escravos das duas freguesias. Um traficante-soldado tinha 10 escravos, assim como um escrevente. Outro, sem profissão definida, tinha oito escravos, e um mestre-escola tinha quatro escravos. Vários artesãos pardos possuíam escravos: dois pintores, sendo um com dois; dois alfaiates, uma costureira, um carpinteiro e um sapateiro, que possuíam um escravo cada. Mesmo os que exerciam ocupações mais simples possuíam escravos: um cozinheiro tinha três escravos, um pescador e mesmo um "pobre" tinha um escravo cada um. Na freguesia da Penha, um chefe de família pardo, que vivia da roça, tinha sete escravos, seguido por um carpinteiro com cinco. Uma costureira e um pescador tinham três, e três outros chefes de família tinham dois escravos, enquanto 10 chefes de família tinham um escravo. Entre os agregados, por outro lado, uma costureira "cabra", que residia com um músico pardo, tinha 10 escravos.

Quanto aos chefes de família pretos da fre- guesia de São Pedro, entre os barbeiros um possuía sete escravos. Um cortador de carne possuía cinco, e um calafate quatro. Três famílias pretas possuíam três escravos, cada; seis famílias possuíam dois cada, e nove famílias possuíam um escravo cada. Um procurador, um padeiro e uma doceira possuíam, cada um, um escravo. Dois agregados pretos sem profissão tinham dois escravos cada, outro sem profissão e um agregado padre possuíam um escravo cada. Na freguesia da Penha, um capitão do mato-pescador e um soldadopescador possuíam oito escravos cada. Um soldado-pedreiro e um sem atividade informada possuíam sete cada, enquanto que uma ganhadeira, um pescador e outro sem informação possuíam cinco cada. Três chefes de família pretos possuíam três escravos cada, 10 chefes de família dois escravos cada e apenas quatro possuíam um escravo. Quanto aos agregados pretos, uma costureira tinha dois escravos, dois sem informação, um pescador, um soldado-pescador e um sem ofício tinham um escravo cada.

Alguns estabelecimentos também possuíam escravos, como uma fazenda e alambique com 13 escravos, na Penha, e outro alambique com cinco escravos. As 14 roças e sítios tinham escravos e seis não tinham. Um tinha quatro escravos, dois tinham três, dois tinham dois e sete tinham um escravo, cada, na mesma freguesia.

Em três residências cujos proprietários residiam em outras freguesias, havia uma com dois escravos e duas outras com um escravo cada. Por outro lado, em cinco residências na freguesia da Penha, havia apenas residentes escravos: duas eram habitadas por um escravo de ganho e uma ganhadeira cada, duas habitadas por um escravo cada, e uma por um escravo pescador. Seriam eles os antecedentes dos atuais caseiros?

\section{CONCLUSÕES}

A análise dos dados aqui apresentados nos mostra que não é possível conceber a existência de apenas duas categorias na sociedade daquele perí- 
odo, como as de senhor e de escravo, caracterizando-as como dominantes e dominados. A sociedade colonial urbana era bem mais complexa, pois nela conviviam brancos ricos, médios e pobres, inclusive numerosas mulheres chefes de família. Os libertos, livres pardos e pretos, também faziam parte da mesma sociedade colonial.

Muitos brancos eram pobres, não tinham escravos e trabalhavam, o que vai contra o outro mito da ociosidade dominante no período escravista.

Registram-se significativas diferenças entre pardos e negros, com destaque para o grau de ascensão social dos pardos, a diversidade de suas ocupações, além das especializações, como nas atividades das costureiras - que se assemelham mais à situação das mulheres brancas pobres do que das pretas, cuja atividade como ganhadeiras era quase exclusiva dessa cor e equivalia ao trabalho escravo. Para exemplificar, destaca-se o caso de uma parda que dispunha de 24 escravos, o que permite a comparação com o maior proprietário preto, naquela época, que tinha oito escravos.

Os escravos eram o contingente mais importante nas duas freguesias: 39,5\% em São Pedro e $38,9 \%$ na Penha (superior ao dos chefes de família e agregados). Essa disponibilidade de escravos corrompeu o conjunto da sociedade. Ter um escravo podia ser semelhante a ter uma casa de aluguel para um indivíduo que vivia de rendas, como nalmente, dos próprios escravos.

As freguesias também eram diferentes: a de São Pedro, próxima da área central, aparece com maior concentração de atividades e ocupações de elevado status, em comparação com a freguesia da Penha, em que dominavam os pescadores e soldados. Os pais de família brancos também eram mais numerosos na freguesia de São Pedro, assim como era maior o número de dependentes agregados nessa freguesia. Por outro lado, na da Penha, com quase metade da sua população de cor, os chefes de família pretos e pardos proprietários de escravos eram mais numerosos que na freguesia de São Pedro. Isso nos mostra que, apesar de não haver segregação intraurbana, os espaços residenciais, no seu conjunto, também se diferenciavam entre si.

Esses dados nos levam a refletir sobre a herança do passado colonial, que ébastante grave, mas não se limita apenas à questão da escravidão, embora, sem dúvida, os escravos tenham constituído a camada mais explorada e injustiçada do período.

Finalmente, os dados examinados nos levam a outra conclusão: a das enormes e até radicais diferenças entre a escravidão na sociedade brasileira, no período colonial, e outras realidades aparentemente semelhantes, como a dos Estados Unidos. São diferenças de proporções entre brancos e "negros", entre livres e libertos, entre ricos e pobres, e, sobretudo, as diferentes possibilidades de ascensão social de indivíduos de cor, inclusive africanos, em pleno período escravista, sem mencionar as diferenças relativas às diversas formas de segregação residencial.

(Recebido para publicação em setembro de 2008) (Aceito em janeiro de 2009)

\section{REFERÊNCIAS}

ALGRANTI, Leila Mezan. O feitor ausente. Petrópolis: Vozes, 1988.

ANDRADE, Maria José de Souza. A mão-de-obra escrava em Salvador 1811-1860. São Paulo: Corrupio, 1988.

CARDOSO, Fernando Henrique. Capitalismo e escravidão no Brasil meridional. Rio de Janeiro: Paz e Terra, [1962] 1977. 
CARNEIRO, Edison. Antologia do negro brasileiro. Rio de Janeiro: Agir, [1950] 2005.

CARVALHO, Marcus J. M. de. Liberdade: rotinas e rupturas do escravismo no Recife, 1822-1850. Recife: Ed. UFPE, 2002.

CHALUB, Sidney. Visões da liberdade. São Paulo: Companhia das Letras, 1990.

CONRAD, Robert Edgar. Tumbeiros. O tráfico escravista para o Brasil. São Paulo: Brasiliense, 1985.

COSTA, Avelino de Jesus da. População da Cidade da Baía em 1775. Separata de: Actas do Colóquio Internacional de Estudos Luso-Brasileiros, 5. Coimbra, 1965. v. 1. p.191-274.

COSTA, Emília Viotti da. Da senzala à colônia. São Paulo: Unesp, [1966] 1998.

COUTY, Louis. A escravidão no Brasil. Rio de Janeiro: Fundação Casa de Rui Barbosa, [1881] 1988.

DIAS, Maria Odila Leite da Silva. Quotidiano e poder em São Paulo no século XIX. São Paulo, [1984] 1995.

FONSECA, Luís Anselmo da. A escravidão, o clero e o abolicionismo. Recife: Massangana; Fundação Joaquim Nabuco, [1887] 1988.

FRANKLIN, J. H.; MOSS JR, A. A. Da escravidão à liberdade. Rio de Janeiro, Nórdica, [1947] 1988.

FREITAS, Décio. Escravos e senhores-de-escravos. Caxias do Sul: Universidade de Caxias do Sul, 1977.

FREYRE, Gilberto. Casa-grande \& senzala. Rio de Janeiro: Record, [1933]- 1990.

\section{$\overline{2004}$}

Sobrados e Mucambos. Recife: Ed. Global, [1936]

GORENDER, Jacob. O escravismo colonial. São Paulo: Ática, [1978] 1985.

A escravidão reabilitada. São Paulo: Ática, 1991.

GOULART, Maurício. Escravidão africana no Brasil (das origens à extinção do tráfico). São Paulo: Alfa-Ômega, [1949] 1975.

IANNI, Octavio. As metamorfoses do escravo. São Paulo: Hucitec; Curitiba: Scientia et Labor, [1961] 1988.

KARASH, Mary C. A vida dos escravos no Rio de Janeiro (1808-1850). São Paulo: Companhia das Letras, [1987] 2000 .

LAMOUNIER, Maria Lúcia. Da escravidão ao trabalho livre. Campinas: Papirus, 1988.
LUNA, F. V.; KLEIN, H. S. Evolução da sociedade e economia escravista de São Paulo, de 1750 a 1850. São Paulo: Edusp, 2005.

MAESTRI, Mário. L’esclavage au Brésil. Paris: Karthala, [1988] 1991.

MALHEIRO, Perdigão. A escravidão no Brasil: ensaio histórico, jurídico, social. Petrópolis: Vozes; Brasília, INL, [1866] 1976. 2v.

MAPA de todos os moradores q compreende a Fregz.a de N. Snr.a da Penha desta Cid.e, Bahia, Rio de Janeiro: Archivo da Marinha e Ultramar. Bibliotheca Nacional. 30/01/1775.

MATTOSO, Kátia de Queirós. Ser escravo no Brasil. São Paulo: Brasiliense, [1978] 1988.

MORAES, Evaristo de. A escravidão africana no Brasil (das origens à extinção). Brasília: Ed. UnB; INL, [1933]. 1986.

MOURA, Clóvis. Dicionário da escravidão negra no Brasil. São Paulo: Edusp, 2004.

NABUCO, Joaquim. O abolicionismo. Rio de Janeiro: Nova Fronteira, [1883] 1999.

REIS, João José. Rebelião escrava no Brasil. São Paulo: Companhia das Letras, [1986] 2003.

RUSSELL-WOOD, A. J. R. Escravos e libertos no Brasil colonial. Rio de Janeiro: Civilização Brasileira, [1982] 2005.

SCHWARTZ, Stuart. Segredos internos. São Paulo, Companhia das Letras, [1985] 1988.

Escravos, roceiros e rebeldes. Bauru: Edusc,

SILVA, Maria Beatriz Nizza da Silva. Ser nobre na colônia. São Paulo: Unesp, 2005.

SILVA, Marilena Rosa Nogueira da. Negro na rua: a nova face da escravidão. São Paulo: Hucitec, 1988.

SOARES, Mariza de Carvalho. Devotos da cor. Rio de Janeiro: Civilização Brasileira, 2000.

VASCONCELOS, Pedro de Almeida. Salvador: transformações e permanências. Ilhéus: Editus, 2002.

A aplicação do conceito de segregação residencial ao contexto brasileiro na longa duração. Cidades, Presidente Prudente,SP, Grupo de Estudos Urbanos, n.2, jul./ dez., p. 259-274, 2004

VERGER, Pierre. Fluxo e refluxo do tráfico de escravos entre o golfo do Benin e a Bahia de Todos os Santos: dos séculos XVII a XIX. São Paulo: Corrupio, [1968] 1987. 


\section{RACIAL COMPLEXITY: myth and reality in two Salvador freguesias in 1775}

Pedro de Almeida Vasconcelos

\section{COMPLEXITÉ RACIALE: mythes et réalités dans deux paroisses de Salvador en 1775}

Pedro de Almeida Vasconcelos
The meticulous analysis of data from the Census of 1775 on two freguesias of Salvador (São Pedro and Penha), bring doubt to five dominant myths on slavery in the national imaginary: (1) the exclusivity of slave work in the society; (2) a society just formed by slave owners and slaves; (3) a society where, on one side, live a segment of dominant exploiters and, on the other, dominated explored people; (4) a segregated urban society; (5) a patriarchal society, in which women were submissive and economically subordinates. The results of the census, therefore, bring new subjects to understanding the complexity of our past, what helps to understand the maintenance of the extreme current inequalities, besides showing the existence of space differentiations in the city.

KEYwORDs: slaves, freed men, agregados, freguesias, Salvador.
A partir de l'analyse minutieuse des données du recensement de 1775 concernant deux paroisses de Salvador (São Pedro et Penha) sont remis en question cinq mythes dominants à propos de l'esclavage dans l'imaginaire national: (1) l'exclusivité du travail esclave dans la société; (2) une société formée uniquement de seigneurs et d'esclaves; (3) une société constituée d'une part par un segment de dominants et d'exploiteurs et d'autre part de dominés et d'exploités; (4) une société urbaine ségréguée; (5) une société patriarcale où les femmes étaient soumises et subordonnées économiquement. Les résultats de ce recensement soulèvent donc de nouvelles questions pour la compréhension de la complexité de notre passé, ceci permet de comprendre le maintien d'extrêmes inégalités actuelles et de mettre aussi en évidence l'existence de différenciations spatiales dans la ville.

Mots-CLÉs: esclaves, personnes libres, domestiques, paroisses, Salvador.

Pedro de Almeida Vasconcelos - Professor do Mestrado em Planejamento Territorial e Desenvolvimento Social da Ucsal e Professor do Mestrado em Geografia da UFBa. Ph.D em Geografia pela Université d'Ottawa, Ottawa, Canadá, 1985. Pós Doutorado em Geografia, Université de Paris VI, Paris, 1994-1995. Pesquisador CNPq. Principais publicações: Dois Séculos do Pensamento sobre a Cidade. Ilhéus: Editus, 1999; Salvador: transformações e permanências (1549-1999). Ilhéus: Editus, 2002. Salvador de Bahia (Brésil). Transformations et permanences (1549-2004). Paris, L’Harmattan, 2005. 